OPEN ACCESS

Edited by:

Leonardo Julián Magnoni, Centro Interdisciplinar de Pesquisa Marine e Ambiental (CIIMAR), Portugal

Reviewed by: Ivan Viegas,

University of Coimbra, Portugal Juan Antonio Martos-Sitcha, Institute of Aquaculture Torre de la Sal (CSIC), Spain

*Correspondence:

Tsung-Han Lee thlee@email.nchu.edu.tw

Specialty section:

This article was submitted to

Aquatic Physiology,

a section of the journal

Frontiers in Physiology

Received: 12 November 2017

Accepted: 23 January 2018

Published: 12 February 2018

Citation:

Chang C-H, Huang J-J, Yeh C-Y, Tang C-H, Hwang L-Y and Lee T-H (2018) Salinity Effects on Strategies of

Glycogen Utilization in Livers of Euryhaline Milkfish (Chanos chanos) under Hypothermal Stress.

Front. Physiol. 9:81

doi: 10.3389/fphys.2018.00081

\section{Salinity Effects on Strategies of Glycogen Utilization in Livers of Euryhaline Milkfish (Chanos chanos) under Hypothermal Stress}

\author{
Chia-Hao Chang ${ }^{1}$, Jian-Jun Huang ${ }^{1}$, Chun-Yi Yeh ${ }^{1}$, Cheng-Hao Tang ${ }^{2}$, Lie-Yueh Hwang ${ }^{3}$ \\ and Tsung-Han Lee ${ }^{1,4 *}$ \\ ' Department of Life Sciences, National Chung Hsing University, Taichung, Taiwan, ${ }^{2}$ Department of Oceanography, National \\ Sun Yat-sen University, Kaohsiung, Taiwan, ${ }^{3}$ Mariculture Research Center, Fisheries Research Institute, Council of \\ Agriculture, Yulin, Taiwan, ${ }^{4}$ Agricultural Biotechnology Center, National Chung Hsing University, Taichung, Taiwan
}

The fluctuation of temperature affects many physiological responses in ectothermic organisms, including feed intake, growth, reproduction, and behavior. Changes in environmental temperatures affect the acquisition of energy, whereas hepatic glycogen plays a central role in energy supply for the homeostasis of the entire body. Glycogen phosphorylase (GP), which catalyzes the rate-limiting step in glycogenolysis, is also an indicator of environmental stress. Here, we examined the effects of salinity on glycogen metabolism in milkfish livers under cold stress. A reduction of feed intake was observed in both freshwater (FW) and seawater (SW) milkfish under cold adaptation. At normal temperature $\left(28^{\circ} \mathrm{C}\right)$, compared to the FW milkfish, the SW milkfish exhibited greater mRNA abundance of the liver isoform of GP (Ccpygl), higher GP activity, and less glycogen content in the livers. Upon hypothermal $\left(18^{\circ} \mathrm{C}\right)$ stress, hepatic Ccpygl mRNA expression of FW milkfish surged at $3 \mathrm{~h}$, declined at 6 and $12 \mathrm{~h}$, increased again at $24 \mathrm{~h}$, and increased significantly after $96 \mathrm{~h}$. Increases in GP protein, GP activity, and the phosphorylation state and the breakdown of glycogen were also found in FW milkfish livers after $12 \mathrm{~h}$ of exposure at $18^{\circ} \mathrm{C}$. Conversely, the Ccpygl transcript levels in SW milkfish were downregulated after $1 \mathrm{~h}$ of exposure at $18^{\circ} \mathrm{C}$, whereas the protein abundance of GP, GP activity, and glycogen content were not significantly altered. Taken together, under $18^{\circ} \mathrm{C}$ cold stress, FW milkfish exhibited an acute response with the breakdown of hepatic glycogen for maintaining energy homeostasis of the entire body, whereas no change was observed in the hepatic glycogen content and GP activity of SW milkfish because of their greater tolerance to cold conditions.

Keywords: glycogen phosphorylase, milkfish, liver, low temperature, seawater, fresh water

\section{INTRODUCTION}

Glycogen, a polymer of glucose residues, is a crucial form of energy storage. Catabolism of stored glycogen (i.e., glycogenolysis) occurs through the action of glycogen phosphorylase (GP; EC 2.4.1.1), which releases glucose-1-phosphate from the glycogen polymer and provides glucose for energy required by the organisms. GP is a homodimeric enzyme subjected to allosteric control 
and exhibits transitions between "relaxed" (active) and "tense" (inhibited) conformational states (Johnson, 1992; Agius, 2015). In fish, three isoforms of GP were named according to the tissues in which they occur, including the brain ( $p y g b)$, liver ( $p y g l)$, and muscle $(p y g m)$. The liver and skeletal muscle are two major tissues for glycogen storage. The concentration of glycogen is higher in the liver than in the muscle ( 10 vs. $2 \%$ by weight) (Berg et al., 2002). In the liver, glycogen degradation and synthesis play major roles in regulating blood glucose homeostasis and supplying energy to other tissues (Vornanen and Haverinen, 2011; Polakof et al., 2012).

Elevated blood glucose levels and energy metabolism have been detected in response to stress or environmental fluctuations (Lin et al., 2011; Polakof et al., 2012; Huang et al., 2015). Water temperature is critical to the physiological responses and energy utilization strategies of teleosts. Among different species, the best physiological performance (ex. behavior, feed intake, digestion, growth, and reproduction) was usually found in the optimal ranges (Pörtner et al., 2007; Handeland et al., 2008; Pörtner, 2009; Schram et al., 2013; Payne et al., 2016). Total GP activity of the liver and heart of the crucian carp (Carassius carassius) increased during the summer (Vornanen and Haverinen, 2011). In addition, a two-stage decline in temperature is the main trigger for active foraging and synthesis of glycogen before winter dormancy in the crucian carp, whereas the hepatic glycogen store did not change when the temperature declined steadily (Varis et al., 2016). The rainbow smelt (Osmerus mordax) is a temperate species and can tolerate low temperatures from 0.4 to $-1.5^{\circ} \mathrm{C}$. The production of glycerol is important as an antifreeze in the plasma and other tissues, and at $0.4^{\circ} \mathrm{C}$, the increase in total GP activity promoted the breakdown of glycogen allowing glycerol accumulation in the rainbow smelt (Clow et al., 2008). Conversely, at $8^{\circ} \mathrm{C}$, the gilthead sea bream (Sparus aurata) typically undergoes a multi-organ dysfunction called the "winter syndrome." Furthermore, a reduction in feed intake and accumulation of liver glycogen were detected during pre-winter periods $\left(18^{\circ} \mathrm{C}\right)$ (Couto et al., 2008; Ibarz et al., 2010c).

The milkfish (Chanos chanos) is an economically important species in Southeast Asia and Taiwan. The average temperatures in summer and winter in Taiwan are approximately $28^{\circ} \mathrm{C}$ and $18^{\circ} \mathrm{C}$, respectively. Cold snaps in winter, however, sometimes make the temperature lower than $15^{\circ} \mathrm{C}$, leading to high mortality of this tropical euryhaline species and causing huge economic losses. Acclimation of milkfish to seawater (SW) or fresh water (FW) induces a variety of physiological responses, including changes in their tolerance to hypothermal stress. SW milkfish exhibited better hypothermal tolerance than FW milkfish (Kang et al., 2015). The FW milkfish exhibited higher gill $\mathrm{Na}^{+} / \mathrm{K}^{+}$ATPase activity that might require a greater energy supply compared to that of the SW individuals (Lin et al., 2003; Kang et al., 2015). From transcriptome analyses of hypothermal milkfish (Hu et al., 2015, 2017), the fragments per kilobase of transcript per million reads mapped (FPKM) of GP was found to increase 1.28-fold in FW individuals and decrease to 0.77 -fold in SW fish. Moreover, the protein abundance of lactate dehydrogenase was found to be upregulated in the liver of SW milkfish under hypothermal adaptation, indicating the requirement of a larger energy source under the stressful conditions (Chang et al., 2016b). Hence, the strategies of energy utilization in livers between FW and SW milkfish are proposed to be distinct, leading to different cold tolerance upon hypothermal stress.

Being an important factor for energy supply of fish, the feed intake was found to be lower in the gilthead sea bream under cold stress (Ibarz et al., 2007; Couto et al., 2008). The decreased energy source from feed intake led to a degradation in hepatic glycogen for maintaining blood glucose (Ibarz et al., 2010a). In this study, feed intake and hepatic glycogen content were analyzed in FW and SW milkfish under hypothermal $\left(18^{\circ} \mathrm{C}\right)$ stress. In addition, the partial sequence of Ccpygl was identified. The Ccpygl mRNA abundance and GP activity in the livers of $18^{\circ} \mathrm{C}$-exposed $\mathrm{FW}$ and SW milkfish were compared. Our data illustrated distinct strategies of glycogen utilization corresponding to different low temperature tolerances for FW- and SW-acclimated euryhaline milkfish.

\section{MATERIALS AND METHODS}

\section{Rearing Conditions of Milkfish}

Juvenile milkfish were obtained from a local fish farm in Lukang, Taiwan. Fish were transported to the laboratory, where they were raised in four $400 \mathrm{~L}$ rearing tanks; two with seawater (SW 35\%o) and two with FW, at $28 \pm 1^{\circ} \mathrm{C}$ with a daily $12 \mathrm{~h}$ photoperiod for at least 1 month to reach a steady state (Kang et al., 2013; Chang et al., 2016c; Hu et al., 2017). The water for rearing tanks was continuously circulated through fabricfloss filters, and salinity was measured by a refractometer ATCS (ATAGO, Tokyo, Japan). All experimental animals were fed to satiation at 15:00-16:00 everyday. The milkfish commercial diets contain $24 \%$ crude protein and $3 \%$ crude lipid (FWUSOW Industry, Taichung, Taiwan). In total, 188 milkfish were used in the present study. The protocol for the experimental fish was reviewed and approved by the Institutional Animal Care and Use Committee (IACUC) of the National Chung Hsing University (IACUC Approval No. 105-024 to THL).

\section{Hypothermal Acclimation/Stress Experiments}

For these two experiments, the temperature was maintained at 28 $\pm 1^{\circ} \mathrm{C}$ for the control group and $18 \pm 0.5^{\circ} \mathrm{C}$ for the hypothermal group. The water for hypothermal SW and FW groups was cooled down at a constant rate $\left(2^{\circ} \mathrm{C} \mathrm{h}^{-1}\right)$ with a cooling system (PF-225M, PRINCE, Tainan, Taiwan). After transfer to the $100 \mathrm{~L}$ experimental tanks with a hypothermal $\left(18^{\circ} \mathrm{C}\right)$ or control temperature $\left(28^{\circ} \mathrm{C}\right)$ from the $400 \mathrm{~L}$ rearing tanks, the milkfish were maintained and stabilized in the experimental tanks for at least 2 days. For the hypothermal acclimation experiments, milkfish were kept in four $100 \mathrm{~L}$ experimental tanks/conditions with different temperature $\times$ salinity set-ups ([1] SW/28 ${ }^{\circ} \mathrm{C}$, [2] $\mathrm{FW} / 28^{\circ} \mathrm{C}$, [3] $\mathrm{SW} / 18^{\circ} \mathrm{C}$, and [4] $\mathrm{FW} / 18^{\circ} \mathrm{C}$ ) for 1 week and then sampled ( $n=6$ for each condition). For the hypothermal stress experiments, milkfish were acclimated to $28^{\circ} \mathrm{C}$ followed by a temperature drop to $18^{\circ} \mathrm{C}$ at a rate of $2^{\circ} \mathrm{C}$ per hour, and subsequent sampling at $1,3,6,12,24,48,96$, and $168 \mathrm{~h}$ after 
reaching $18^{\circ} \mathrm{C}$ ( $n=6$ for each of the salinities). During the experiments, milkfish were fed once per day. The experimental fish were euthanized the morning after the end of the experiment and anesthetized with $0.5 \%$ 2-phenoxyethanol before sampling. All efforts were made to minimize suffering and distress. The average body weight and average total length of sampled milkfish were $13.1 \pm 2.3 \mathrm{~g}$ and $10.2 \pm 1.3 \mathrm{~cm}$, respectively. Milkfish livers were dissected quickly, immersed in liquid nitrogen, and stored at $-80^{\circ} \mathrm{C}$ until the following analyses.

\section{Feed-Intake Experiments}

In addition to the hypothermal acclimation/stress experiments, 32 experimental milkfish were used in feed-intake experiments. Four experimental conditions ([1] SW/28 ${ }^{\circ} \mathrm{C}$, [2] $\mathrm{FW} / 28^{\circ} \mathrm{C}$, [3] $\mathrm{SW} / 18^{\circ} \mathrm{C}$, and $[4] \mathrm{FW} / 18^{\circ} \mathrm{C}$ ) of the feed-intake experiments were performed, and eight experimental animals were used in each condition. For each experimental condition, a single milkfish was reared in a $100 \mathrm{~L}$ experimental tank for 1 week and used for feed-intake measures only once. During the experimental period, this milkfish in the experimental tank was fed once (15:0016:00) daily. On the 17 day of the experiment, the feed-intake of the milkfish in the experimental condition was evaluated. Several $1.5 \mathrm{~mL}$-tubes of feed pellets were prepared before feeding. $0.02 \mathrm{~g}$ milkfish commercial feed pellets that were stable in water were first weighed and packed in each $1.5 \mathrm{~mL}$ tube, and the number of feed pellets in the tube was counted. After feeding, all amounts (tubes) of feed pellets and the pellet residue in the experimental tank were counted. The uptake of feed pellets of each experimental milkfish per day $\left(\mathrm{g} \mathrm{fish}^{-1}\right.$ day $^{-1}$ ) was worked out by subtracting the amount of pellet residue in the tank from the number of feeding pellets and converting to weight (g) of feed. The average feed-intake of milkfish in each condition was derived from eight individuals.

\section{Total RNA Extraction and Reverse Transcription}

Total RNA samples were isolated using the Tripure Isolation Reagent following the manufacturer's instructions. The genomic DNA contamination in RNA samples was eliminated by using the RNAspin Mini RNA isolation kit (GE Healthcare, Piscataway, NJ, USA). RNA integrity was verified by electrophoresis in $1 \%$ agarose-gel. The purity and concentration of extracted RNA were measured with a NanoDrop 2000 (Thermo Fisher Scientific, Waltham, MA, USA). Purified RNA with an A260/A280 ratio of between 1.8 and 2.0 was used for the following experiments. Firststrand cDNA was synthesized by reverse transcribing $1 \mu \mathrm{g}$ of the total RNA and the iScript Reverse Transcription Supermix (BioRad Laboratories, Hercules, CA, USA) was used according to the manufacturer's instructions. The cDNA samples were stored at $-20^{\circ} \mathrm{C}$ before analyses.

\section{cDNA Cloning and Sequence Analysis}

The partial sequence of Ccpygl was identified (KY923199), and the primers were designed by the Primer 3 Plus based on highly conserved regions compared with other teleosts from the NCBI database (Table 1). For PCR amplification, $2 \mu \mathrm{L}$ of cDNA from the milkfish liver was used as the template in a $50 \mu \mathrm{L}$ PCR
TABLE 1 | Reference proteins from NCBI database for Pygl phylogenetic analysis.

\begin{tabular}{|c|c|c|}
\hline Species & Gene name & $\begin{array}{l}\text { Accession } \\
\text { number }\end{array}$ \\
\hline Astyanax mexicanus & $\begin{array}{l}\text { PREDICTED: glycogen } \\
\text { phosphorylase liver form }\end{array}$ & XP 006632545.1 \\
\hline $\begin{array}{l}\text { Cynoglossus } \\
\text { semilaevis }\end{array}$ & $\begin{array}{l}\text { PREDICTED: glycogen } \\
\text { phosphorylase liver form }\end{array}$ & XP 008311194.1 \\
\hline Danio rerio & Glycogen phosphorylase, liver form & NP001008538.1 \\
\hline Fundulus heteroclitu & $\begin{array}{l}\text { PREDICTED: glycogen } \\
\text { phosphorylase liver form }\end{array}$ & XP 012727698.1 \\
\hline $\begin{array}{l}\text { Haplochromis } \\
\text { burtoni }\end{array}$ & $\begin{array}{l}\text { PREDICTED: glycogen } \\
\text { phosphorylase liver form }\end{array}$ & XP 005946111.1 \\
\hline Homo sapiens & $\begin{array}{l}\text { Liver glycogen phosphorylase } \\
\text { Glycogen phosphorylase, liver form } \\
\text { isoform } 1 \\
\text { Liver glycogen phosphorylase }\end{array}$ & $\begin{array}{l}\text { AAC17450.1 } \\
\text { NP002854.3 } \\
\text { AAC23504.1 }\end{array}$ \\
\hline Ictalurus punctatus & Glycogen phosphorylase, liver form & AHH39573.1 \\
\hline $\begin{array}{l}\text { Larimichthys } \\
\text { crocea }\end{array}$ & $\begin{array}{l}\text { Glycogen phosphorylase, liver form } \\
\text { PREDICTED: glycogen } \\
\text { phosphorylase liver form }\end{array}$ & $\begin{array}{l}\text { KKF13421.1 } \\
\text { XP 010752900.1 }\end{array}$ \\
\hline $\begin{array}{l}\text { Lepisosteus } \\
\text { oculatus }\end{array}$ & $\begin{array}{l}\text { PREDICTED: glycogen } \\
\text { phosphorylase liver form }\end{array}$ & XP 006632545.1 \\
\hline Mus musculus & $\begin{array}{l}\text { Glycogen phosphorylase, liver form } \\
\text { Liver glycogen phosphorylase }\end{array}$ & $\begin{array}{l}\text { NP573461.2 } \\
\text { AAH13636.1 }\end{array}$ \\
\hline Maylandia zebra & $\begin{array}{l}\text { PREDICTED: glycogen } \\
\text { phosphorylase liver form }\end{array}$ & XP 004540100.1 \\
\hline $\begin{array}{l}\text { Neolamprologus } \\
\text { brichardi }\end{array}$ & $\begin{array}{l}\text { PREDICTED: glycogen } \\
\text { phosphorylase liver form }\end{array}$ & XP 006798715.1 \\
\hline Oryzias latipes & $\begin{array}{l}\text { PREDICTED: glycogen } \\
\text { phosphorylase liver form }\end{array}$ & XP 004082115.1 \\
\hline $\begin{array}{l}\text { Oreochromis } \\
\text { niloticus }\end{array}$ & $\begin{array}{l}\text { PREDICTED: glycogen } \\
\text { phosphorylase liver form }\end{array}$ & XP 003442910.1 \\
\hline Poecilia Formosa & $\begin{array}{l}\text { PREDICTED: glycogen } \\
\text { phosphorylase liver form }\end{array}$ & XP 014849665.1 \\
\hline Poecilia latipinna & $\begin{array}{l}\text { PREDICTED: glycogen } \\
\text { phosphorylase liver form }\end{array}$ & XP 014887185.1 \\
\hline Pundamilia nyererei & $\begin{array}{l}\text { PREDICTED: glycogen } \\
\text { phosphorylase liver form }\end{array}$ & XP 005736772.1 \\
\hline Rattus norvegicus & Glycogen phosphorylase, liver form & NP071604.1 \\
\hline Salmo salar & Glycogen phosphorylase, liver form & XP014067148.1 \\
\hline Scleropages formosus & Glycogen phosphorylase, liver form & KPP79726.1 \\
\hline Stegastes partitus & $\begin{array}{l}\text { PREDICTED: glycogen } \\
\text { phosphorylase liver form }\end{array}$ & XP 008298301.1 \\
\hline Takifugu rubripes & $\begin{array}{l}\text { PREDICTED: glycogen } \\
\text { phosphorylase liver form }\end{array}$ & XP 003962378.1 \\
\hline
\end{tabular}

reaction containing $0.25 \mu \mathrm{M}$ dNTPs, $2 \mathrm{U}$ of Ex-Taq polymerase, and $0.1 \mu \mathrm{L}$ of cloning primer. PCR products were ligated into the pGM-T vector and sequenced. The amino acid sequence of GPL was used to build a phylogenetic tree using MEGA 6, and the tree was built using the maximum likelihood method in 1,000 bootstraps.

\section{Real-Time PCR}

The mRNA expression was detected by KAPA SYBR FAST qPCR Kit Master Mix and quantified with the Mini Opticon real-time PCR system. The amplification efficiencies of the 
primers (Table 2) were evaluated to be $90-105 \%$, and the $r^{2}$ of the serial dilutions was evaluated to be 0.99 . A single peak appeared in the melting curve analyses and the presence of a single amplification product was observed using 1.5\% agarose gel. The mRNA expression of Ccgpl were normalized with the Chanos chanos 60S acidic ribosomal protein P2 (Ccrplp2) gene from the same cDNA sample. The expression levels of Ccrplp2 were not significantly different among various groups (Table 3 ). The PCR reactions contained $8 \mu \mathrm{L}$ of cDNA, $2 \mu \mathrm{L}$ of $\mathrm{qPCR}$ primer $(2 \mu \mathrm{M})$, and $10 \mu \mathrm{L}$ of SYBR Master Mix. The liver samples of the four experimental groups $\left(\mathrm{FW} / 28^{\circ} \mathrm{C}, \mathrm{FW} / 18^{\circ} \mathrm{C}\right.$, $\mathrm{SW} / 28^{\circ} \mathrm{C}$, and $\mathrm{SW} / 18^{\circ} \mathrm{C}$ ) were pooled and used as the internal control (IC) among different qPCR analyses. The relative gene expression formula was $2^{\wedge}-\left[\left(\mathrm{Ct}_{C c g p l, \mathrm{n}}-\mathrm{Ct}_{C c r p l p 2, \mathrm{n}}\right)-\left(\mathrm{Ct}_{C c g p l, \mathrm{IC}}\right.\right.$ - $\mathrm{Ct}_{\text {Ccrplp2,IC) }}$ (Livak and Schmittgen, 2001).

\section{Immunoblotting}

The immunoblotting protocol was modified from Chang et al. (2016c). The milkfish livers were suspended in SEID medium (150 mM sucrose, $10 \mathrm{mM}$ EDTA, $50 \mathrm{mM}$ imidazole, $0.1 \%$ sodium deoxycholate; $\mathrm{pH} 7.5$ ) containing protease inhibitor (vol/vol: 25:1; Roche, Mannheim, Germany) and were homogenized with a Polytron PT1200E homogenizer (Lucerne, Switzerland) at maximum speed. The homogenates were then centrifuged at $10,000 \times \mathrm{g}$ at $4{ }^{\circ} \mathrm{C}$ for $10 \mathrm{~min}$. Protein concentrations of the supernatants were determined using reagents from the Protein Assay Kit (Bio-Rad), and bovine serum albumin (Sigma-Aldrich, St. Louis, MO, USA) was used as a standard. The homogenates containing $50 \mu \mathrm{g}$ were heated at $60^{\circ} \mathrm{C}$ for $15 \mathrm{~min}$ and fractionated by electrophoresis on SDS containing $8 \%$ polyacrylamide gels. The pre-stained protein molecular weight marker (\#26616, Thermo) was applied in electrophoresis. The separated proteins were transferred to $0.45 \mu \mathrm{m}$ PVDF blotting membranes (Millipore, Bedford, MA, USA). The PVDF membranes were incubated for $1 \mathrm{~h}$ in PBST with 5\% (wt/vol) nonfat dried milk to minimize non-specific binding.

TABLE 2 | Primer sequences used in this study.

\begin{tabular}{llll}
\hline Gene & Primers & Sequence $\left(\mathbf{5}^{\prime} \mathbf{- 3}^{\prime}\right)$ & Application \\
\hline Ccpygl & F793 & AAC ACAATG AGG CTG TGG TC & PCR \\
& R2458 & GAG TGG ACG AAG ATG GTG AT & \\
& qF24 & GAC TT AAC GTC GGC GAT TAC & qPCR \\
& qR158 & GAA GCA GGA GTA Tा TGT GGT G & \\
\hline Ccrplp2 & qF & GTT ACC GGT CGG CCG TTG A & qPCR \\
& qR & AGA AGT CCA AAA AAG GAG CTT CCT & \\
\hline
\end{tabular}

TABLE 3 | The $\triangle$ Ct value of mRNA expression of Ccrplp2 in liver milkfish.

\begin{tabular}{lcccc}
\hline & $\mathbf{F W} / \mathbf{2 8}^{\circ} \mathbf{C}$ & $\mathbf{F W} / \mathbf{1 8}{ }^{\circ} \mathbf{C}$ & $\mathbf{S W} / \mathbf{2 8}^{\circ} \mathbf{C}$ & $\mathbf{S W} / \mathbf{1 8}{ }^{\circ} \mathbf{C}$ \\
\hline Ccrplp2 & $1.40 \pm 0.25$ & $1.16 \pm 0.22$ & $1.36 \pm 0.19$ & $1.14 \pm 0.14$ \\
\hline
\end{tabular}

Values are means \pm SEM, $n=6$. There was no significant difference among various groups.
The blots were incubated with the primary antibody (GP, 1:10,000; GTX124390; Genetex, Irvine, CA, USA; GAPDH, 1:5,000; GTX100118; Genetex) overnight at $4^{\circ} \mathrm{C}$, followed by incubation with the HRP-conjugated secondary antibody (goat anti-rabbit IgG, 1:10,000; GTX213110; Genetex) for $1 \mathrm{~h}$ at $28^{\circ} \mathrm{C}$. The blots were developed with the Immobilon Western Chemiluminescent HRP substrate (Millipore). The images were photographed using the universal hood with a cooling-chargecoupled device (CCD) camera (ChemiDoc $\mathrm{XRS}^{+}$, Bio-Rad) and analyzed with ImageLab software version 3.0 (Bio-Rad) to normalize numerical values compared to the relative intensities of immunoreactive bands. The protein of GP was detected as a single immunoreactive band at $93 \mathrm{kDa}$ (Figure S1).

\section{Glycogen Phosphorylase (GP) Activity}

Functional GP is capable of binding to glycogen when the enzyme is in the R (relaxed) state. The phosphorylated GP is automatically changed to the $\mathrm{R}$ state, whereas unphosphorylated GP in the T (tense) state is regulated by AMP of the allosteric effector and then transformed to the R state. The total GP activity consists of detected activity of both the R (determined by $\mathrm{AMP}^{-}$ assay buffer) and $\mathrm{T}$ (determined by $\mathrm{AMP}^{+}$assay buffer) states (Johnson, 1992; Clow et al., 2008; Vornanen and Haverinen, 2011; Bolinger and Rodnick, 2014; Agius, 2015). The GP activity was determined according to the NAPDH-linked method with modification. The direction of glycogenolysis by determination of NAPDH was enzymatically coupled to phosphoglucomutase and glucose-6-phosphate dehydrogenase. The liver from each milkfish was dissected quickly and immersed in liquid nitrogen. A $10 \mathrm{mg}$ sample of liver tissue was rapidly homogenized in $1 \mathrm{~mL}$ buffer (100 mM imidazole, $100 \mathrm{mM} \mathrm{NaF}, 2 \mathrm{mM}$ EDTA, $0.1 \mathrm{mM}$ PMSF) using a Polytron PT1200E at the maximal speed for $5 \mathrm{~s}$ on ice. The homogenates were centrifuged at $5,000 \times \mathrm{g}$, at $4^{\circ} \mathrm{C}$ for $5 \mathrm{~min}$. The supernatants were used for the GP activity assay. The GP activity assay solution $(50 \mathrm{mM}$ potassium-phosphate buffer, $0.2 \mathrm{mg} / \mathrm{mL}$ glycogen, $0.1 \mathrm{mM}$ EDTA, $15 \mathrm{mM} \mathrm{MgCl}_{2}$, $6.5 \mathrm{mM} \mathrm{NADP}{ }^{+}, 0.001 \mathrm{mg} / \mathrm{mL}$ glucose-1,6-bisphosphate, 10 $\mathrm{U} / \mathrm{mL}$ phosphoglucomutase, $10 \mathrm{U} / \mathrm{mL}$ glucose-6-phosphate dehydrogenase) was the $5^{\prime} \mathrm{AMP}^{-}$assay buffer for determining $\mathrm{GP}$ activity in the R-state. Conversely, the $5^{\prime} \mathrm{AMP}^{+}$assay buffer for determining total GP activity (R+T-state) was the GP activity assay solution plus $1.6 \mathrm{mM} 5^{\prime} \mathrm{AMP}$. The sample of $25 \mu \mathrm{L}$ from each fish was loaded into each well, together with $175 \mu \mathrm{L}$ of the $5^{\prime} \mathrm{AMP}^{-}$or $5^{\prime} \mathrm{AMP}^{+}$assay buffer. Each sample was assayed in triplicate. The 96-well microplate was analyzed every $1 \mathrm{~min}$ for up to $5 \mathrm{~min}$ in the VERSAmax microplate reader at $340 \mathrm{~nm}$ and $28^{\circ} \mathrm{C}$. Serial dilution of NADPH $(50,25,12.5,6.25$, and $3.125 \mu \mathrm{g}$ in $25 \mu \mathrm{L}$ sample buffer) were prepared for the standard curve.

\section{Glycogen Contents}

For quantification of glycogen, $50 \mathrm{mg}$ of milkfish livers were homogenized in $\mathrm{ddH}_{2} \mathrm{O}$. Then the homogenates were boiled for $10 \mathrm{~min}$ to inactive enzymes. The boiled samples were centrifuged at $18,000 \times \mathrm{g}$ for $10 \mathrm{~min}$ to remove insoluble material. The glycogen contents were subsequently determined using the glycogen colorimetric/fluorometric assay kit (K646100, Biovision, Milpitas, CA, USA) following the manufacturer's 
instructions. Then, $5 \mu \mathrm{L}$ of the $40 \times$ dilution of liver samples were added to each well of the 96-well microplate, and the volume was brought to $50 \mu \mathrm{L}$ with the hydrolysis buffer incubated at $28^{\circ} \mathrm{C}$ for $30 \mathrm{~min}$. Then, development buffer mixture was added and incubated for $30 \mathrm{~min}$ at $28^{\circ} \mathrm{C}$. Serial dilution of glycogen $(0.04,0.08,0.12,0.16$, and $0.2 \mu \mathrm{g}$ in $50 \mu \mathrm{L}$ hydrolysis buffer) was prepared for the standard curve. The absorbance was measured in the VERSAmax microplate reader at $570 \mathrm{~nm}$ and the glycogen standard curve was used to calculate the glycogen concentration of the samples.

\section{Statistical Analysis}

Values are expressed as the mean \pm SEM (standard error of mean). The quantitative values of 1 -week data from hypothermal and control groups were determined by two-way analysis of variance (ANOVA) followed by Tukey's HSD post-hoc test on R version 3.4.2 ( $\mathrm{R}$ foundation, Vienna, Austria). Data from timecourse experiments were compared using the one-way ANOVA analysis with Dunnett's pairwise method on $\mathrm{R}$ version 3.4.2, using the $0 \mathrm{~h}$ data as the control. The significance level was set at $P<0.05$.

\section{RESULTS}

\section{Hypothermal Effects on Feed Intake between FW and SW Milkfish}

The feed intake of milkfish was significantly affected by water temperature; the average feed intake per day for FW- and SWacclimated milkfish was $0.115 \pm 0.009 \mathrm{~g}$ and $0.115 \pm 0.013 \mathrm{~g}$ at $28^{\circ} \mathrm{C}$, whereas it was reduced to $0.025 \pm 0.003 \mathrm{~g}$ and $0.039 \pm$ $0.005 \mathrm{~g}$, respectively, under hypothermal acclimation (Figure 1). The two-way ANOVA analyses revealed that feed intake was

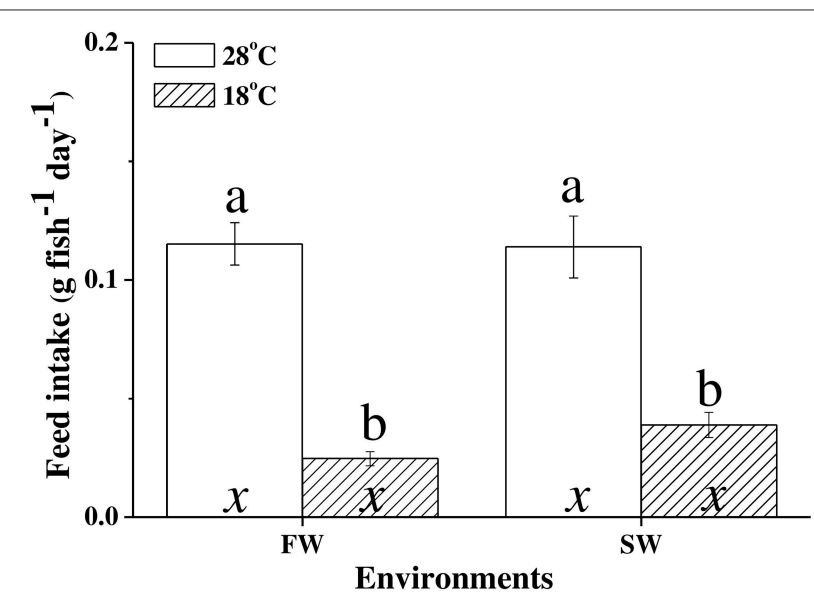

FIGURE 1 | Feed intake ( $\mathrm{g}$ fish $^{-1}$ day $^{-1}$ ) between hypothermal freshwater $(\mathrm{FW})$ and seawater (SW) milkfish. Value are means $\pm \mathrm{SEM}, n=8$. Different letters (a vs. b) indicate significant differences between the $28^{\circ} \mathrm{C}$ and $18^{\circ} \mathrm{C}$ group at the same salinity, and the letter " $x$ " indicate no significant difference between the FW and SW group at the same temperature. The TukeyHSD pairwise comparison was used following two-way ANOVA, $P<0.05$ affected by hypothermal acclimation, whereas the synergistic interaction did not significantly affect feed intake (Table 4).

\section{Phylogenetic Tree and Tissue Distribution of Ccpygl}

The partial sequence of Ccpygl (1,606 bp, accession number: KY923199) was cloned from the liver of milkfish. This partial amino acid sequence was simultaneously confirmed to be the liver isoform of GP ( $p y g l)$ by phylogenetic analyses in comparison with all three isoforms of GP (i.e., liver isoform, [pygl]; muscle isoform $[p y g m]$; and brain isoform $[p y g b]$ ) of other species (Figure S2). Subsequent phylogenetic analyses revealed that the amino acid sequence of Pygl of milkfish was highly similar to Pygl sequences of Mexican tetra (Astyanax mexicanus; 89\%) and channel catfish (Ictalurus punctatus; 87\%) and was categorized in the branch of Ostariophysi (Figure 2). Among the tissues collected from the SW milkfish, Ccpygl expression determined by qPCR was found to be primarily abundant in the liver. In addition to the liver, lower expression of Ccpygl was detected in the brain, gills, and kidney (Figure 3).

\section{Salinity Effects on Glycogen Catabolism in the Hypothermal Acclimation Experiments}

At $28^{\circ} \mathrm{C}$, the mRNA expression of Ccpygl and GP activity were significantly higher in the livers of SW milkfish than in those of FW milkfish (Figures 4A,C). The glycogen storage in the livers of SW milkfish, however, was lower than in those of the FW group (Figure 4D). Conversely, in the hypothermal acclimation experiments, the mRNA expression profiles of Ccpygl in the livers were upregulated in FW milkfish and downregulated in SW fish (Figure 4A). Hepatic GP protein (Figure 4B) and GP activity (Figure 4C) were also increased in FW milkfish under hypothermal acclimation, but not significantly different than in hypothermal SW-acclimated individuals (Figures 4B,C). Meanwhile, in the hypothermal acclimation experiments, glycogen contents were found to downregulate in the livers of FW milkfish, whereas they were slightly, but not significantly $(p=0.247)$, elevated in the livers of SW milkfish (Figure 4D). The two-way ANOVA analyses revealed that $C c p y g l$, GP activity, and glycogen content were affected by synergistic interaction between temperature and salinity (Table 4).

\section{Acute Changes in Ccpygl mRNA Expression in the Hypothermal Stress Experiments}

The acute mRNA expression of Ccpygl in milkfish livers was determined by qPCR at $0 \mathrm{~h}$ (control) and after hypothermal stress for $1,3,6,12,24,48,96$, and $168 \mathrm{~h}$ in $\mathrm{FW}$ (Figure 5A) or $\mathrm{SW}$ (Figure 5B). In hypothermal FW, the mRNA expression of Ccpygl responded in a biphasic manner with a rapid increase peaking at $3 \mathrm{~h}$ and a second elevation at $96 \mathrm{~h}$ post transfer (Figure 5A). Conversely, in hypothermal SW, a significant downregulation of Ccpygl mRNA abundance occurred from $1 \mathrm{~h}$ post transfer to the end of the hypothermal stress experiment (168 h post transfer) (Figure 5B). 
TABLE 4 | Results of two-way ANOVA evaluating the source of temperature and salinity variations in livers of milkfish.

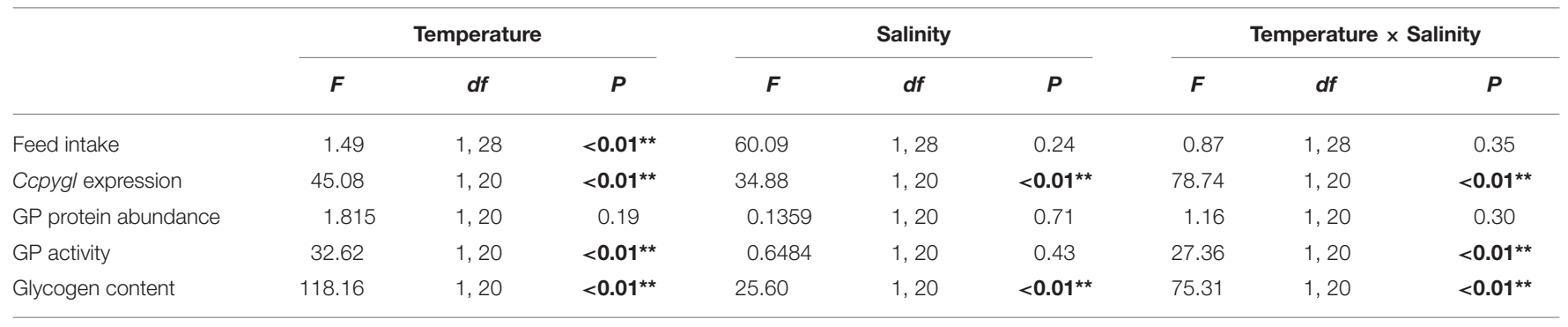

$D f$, degree of freedom; F, F statistic; ${ }^{*} P \leq 0.05 ;{ }^{* *} P \leq 0.01$. Values in bold indicate significant differences.

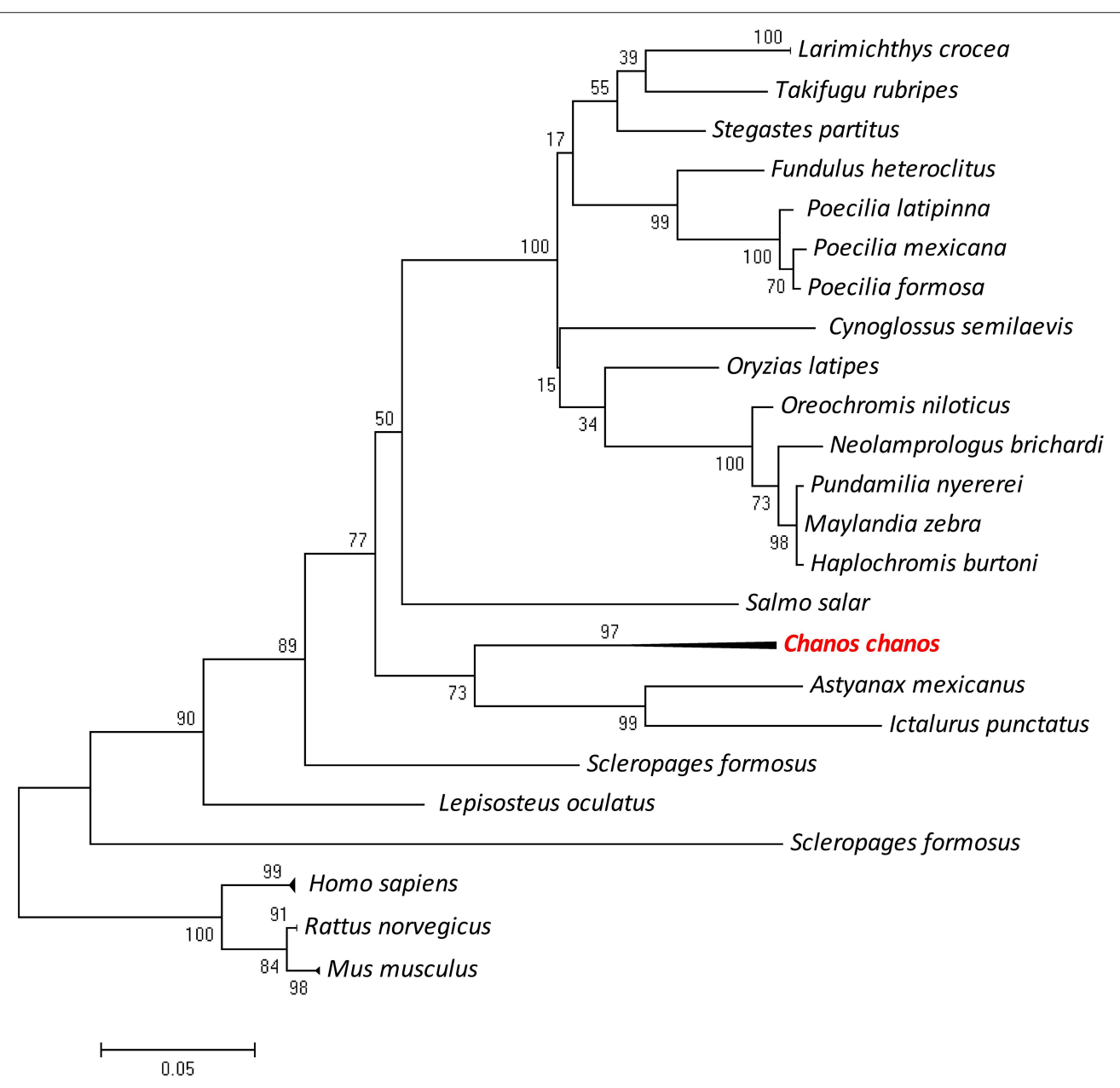

FIGURE 2 | Phylogenetic analysis of milkfish (Chanos chanos) liver isoform of glycogen phosphorylase (Pygl) proteins based on amino acid sequences using the maximum likelihood method. The results were confirmed by 1000 bootstraps. Sequence accession numbers of different proteins are listed in Table 2 .

\section{Different Patterns of Hepatic Glycogen Catabolism between FW and SW Milkfish in the Hypothermal Stress Experiments}

The protein abundance of GP, GP activity and glycogen contents in the livers of milkfish were analyzed at 0 (control), 12, 24, and $168 \mathrm{~h}$ of $18^{\circ} \mathrm{C}$-exposure. The protein abundance of GP and GP activity in the livers of FW milkfish was significantly upregulated after 12, 24, and $168 \mathrm{~h}$ (approximately 1.5-fold) of $18^{\circ} \mathrm{C}$-exposure (Figures 6A,C). In SW milkfish, however, no significant difference in protein abundance of GP and GP activity were found among different time-point groups in the hypothermal stress experiments (Figures 6B,D). Moreover, 


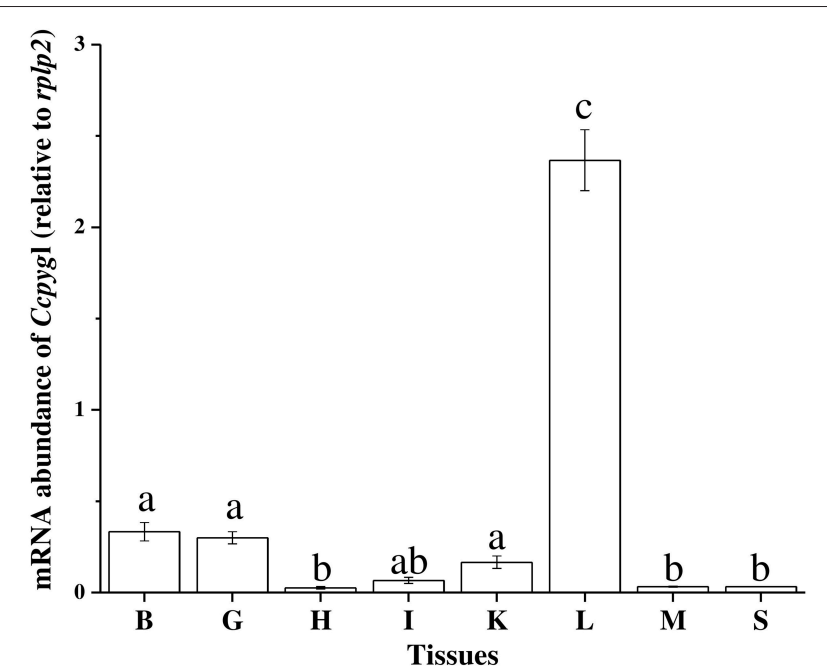

FIGURE 3 | Tissue distribution of Ccpygl (Chanos chanos liver isoform of glycogen phosphorylase) mRNA expression of the milkfish detected by qPCR. Values are means \pm SEM, $n=3$. B, brain; G, gill; $H$, heart; I, intestine; K, kidney; L, liver; M, muscle; S, spleen.

hepatic glycogen contents were significantly downregulated in FW milkfish after $12 \mathrm{~h}$ of hypothermal stress, and onward (Figure 6E). Conversely, in SW there was no significant change among different time-points after exposure to $18^{\circ} \mathrm{C}$ (Figure 6F).

\section{The Percentage of the Active form of GP in the Hypothermal Stress Experiments}

The R-state is the phosphorylated state of GP with higher activity to degrade glycogen, whereas the T-state is the dephosphorylated state of GP with lower activity to breakdown glycogen. The percentage of the active form of GP activity was calculated as the results of GP (R-state; determined by $\mathrm{AMP}^{-}$assay buffer) divided by the total GP activity $(\mathrm{R}+\mathrm{T}$-state; determined by $\mathrm{AMP}^{+}$assay buffer). Increasing percentages indicated that the levels of phosphorylation of GP in FW milkfish were significantly upregulated after 12,24 , and $168 \mathrm{~h}$ of exposure to $18^{\circ} \mathrm{C}$ (Figure 7A). However, the phosphorylation level of GP was not significantly different to that in SW milkfish in the hypothermal stress experiments (Figure 7B).

\section{DISCUSSION}

The most important finding of the present study was that under hypothermal stress, salinity affected the glycogen utilization strategy of milkfish. The mRNA expression, protein abundance, and GP activity were upregulated and correlated with glycogen catabolized (correlation coefficient: mRNA, -0.88 ; protein, -0.60; GP activity, -0.81) in FW-acclimated milkfish at $18^{\circ} \mathrm{C}$. Moreover, mRNA expression of Ccgpl behaved in a biphasic manner, with an early and late phase, and the protein abundance of GP and phosphorylation state of GP were regulated acutely in FW-acclimated individuals under hypothermal stress. The GP activity and glycogen contents, however, were not significantly altered in SW-acclimated milkfish when exposed to $18^{\circ} \mathrm{C}$. Only the mRNA expression of Ccgpl was downregulated after $1 \mathrm{~h}$ exposure at $18^{\circ} \mathrm{C}$.

\section{Phylogenetic Relationship of Glycogen Phosphorylase in Milkfish}

Near et al. (2014) described the phylogenetic relationship of gonorynchiform fishes by using several nuclear DNA genes. The milkfish (Chanos chanos) is a primitive species originating in the Mesozoic and classified in Chanidae of Gonorynchiformes. The phylogenetic tree of ossification showed that milkfish was classified with the original ray-finned fish (Arratia and Bagarinao, 2010). The pygl gene of milkfish was classified in the Ostariophysi family. This gonorynchiform species is close to Characiformes (Astyanax mexicanus) and Siluriformes (Ictalurus punctatus) species (Arratia and Bagarinao, 2010). Three isoforms of GP were highly similar in their amino acid sequences. They were encoded by three genes, pygl, pygm, and pygb, which were mainly distributed in the liver, muscle, and brain, respectively (Tseng et al., 2007; Polakof et al., 2012). In the present study, the CcPygl sequence was confirmed according to the phylogenetic tree of these three isoforms.

\section{Salinity Effects on Glycogen Utilization in the Livers of Milkfish}

The liver is an important organ for energy metabolism, and is responsible for glycogen and glucose turnover, fatty acid synthesis, and gluconeogenesis in all teleosts (Polakof et al., 2012). Differentially expressed genes related to energy metabolism were recently reported in the livers of the gilthead sea bream ( $S$. aurata), after hypo-osmotic challenge (MartosSitcha et al., 2016). The glycogen levels and GP activity were not changed under hypo-osmotic stress in the livers of the gilthead sea bream (Laiz-Carrión et al., 2005) as well as another marine species, the Senegalese sole (Solea senegalensis) (Arjona et al., 2009). Similarly, in freshwater goldfish (Carassius auratus), the levels of hepatic glycogen did not change under hyperosmotic stress (Luz et al., 2008). The hepatic glycogen contents of tilapia (Oreochromis mossambicus) and rainbow trout (Oncorhynchus mykiss) were utilized in an acute phase upon hyperosmotic challenge (Chang et al., 2007; Singer et al., 2007). Further, the hepatic glycogen may have provided carbohydrates for glycolysis to maintain branchial ionic homeostasis in tilapia, gilthead sea bream, and rainbow trout in time-course experiments (Soengas et al., 1993; Sangiao-Alvarellos et al., 2005; Chang et al., 2007). The milkfish is a marine euryhaline species with branchial $\mathrm{Na}^{+} / \mathrm{K}^{+}$-ATPase (NKA), the major energy-requiring pump for maintaining ionic homeostasis, more highly expressed in FWacclimated individuals than in SW-acclimated ones. Therefore, the energy demand for ionoregulation was higher in milkfish under hypo-osmotic stress (Jana et al., 2006; Tang et al., 2010; Kang et al., 2015) reported that milkfish fry acclimated to $25 \%$ o seawater had the lowest level of hepatic glycogen, but exhibited the best growth performance $\left(1.2 \% \mathrm{~g}\right.$ day $\left.^{-1}\right)$ and muscle protein content. It is obvious that changes in environmental salinity influence strategies of energy accumulation and growth 

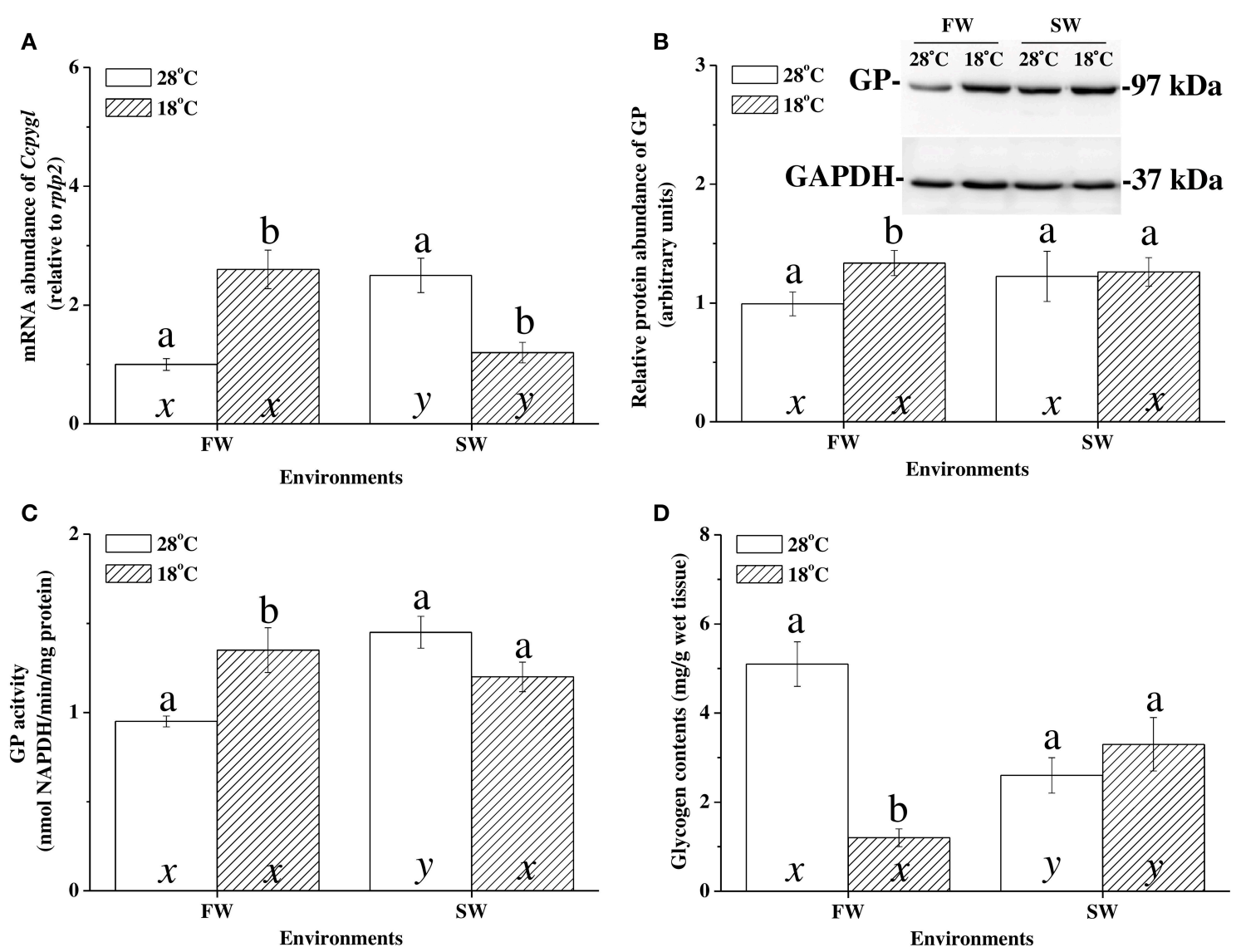

FIGURE 4 | The hypothermal acclimation experiments revealed the glycogen catabolism pattern in livers of freshwater (FW) and seawater (SW) milkfish after 1-week hypothermal stress. (A) mRNA expression of Ccpygl, (B) abundance of GP protein, (C) GP activity, and (D) glycogen content. Values are means $\pm \mathrm{SEM}, n=6$. Different letters (a vs. $b$ and $x$ vs. y) indicate significant differences between the $28^{\circ} \mathrm{C}$ and $18^{\circ} \mathrm{C}$ group at the same salinity, and the FW and SW group at the same temperature, respectively. The TukeyHSD pairwise comparison followed the two-way ANOVA, $P<0.05$.

performance in milkfish (Jana et al., 2006). The present study further revealed that the energy storage or utilization strategies of milkfish obviously vary depending on the environmental salinities to which they are acclimated. On the other hand, the acute utilization strategies of hepatic glycogen in milkfish for the entire body upon hypo-osmotic challenge are still unknown. Future studies will focus on the mechanism by which hepatic glycogen in milkfish is used for maintaining ionic homeostasis upon hypo-osmotic challenge.

\section{Temperature Effects on Glycogen Utilization in the Livers of Milkfish}

Low temperature appears to be an important factor to regulate glycogen storage in the crucian carp (Carassius carassius), a temperate species. A two-step cooling down procedure (from $18^{\circ} \mathrm{C}$ to $7.5^{\circ} \mathrm{C}$ maintained for 30 days, then from 7.5 to $2^{\circ} \mathrm{C}$ maintained until 60 days) induced hepatic glycogen storage, whereas the direct cooling-down (to $2^{\circ} \mathrm{C}$ ) procedure did not change the glycogen content in the livers of the crucian carp (Varis et al., 2016). In the gilthead sea bream, a subtropical species, the reduction of feed intake was significantly correlated with environmental temperatures and liver glycogen deposition was observed in the low-temperature $\left(18^{\circ} \mathrm{C}\right)$ group rather than in the normal-temperature $\left(25^{\circ} \mathrm{C}\right)$ group (Couto et al., 2008; Enes et al., 2008). Similarly, reduction of feed intake was also observed in the $\mathrm{FW}$ - and SW-acclimated milkfish under hypothermal $\left(18^{\circ} \mathrm{C}\right)$ adaptation. When environmental temperature decreased to $8^{\circ} \mathrm{C}$, however, the energy utilization strategy of sea bream changed to the production of nonpolar and polar lipids, whereas the glycogen content in the livers was not significantly changed. In environments with much lower temperatures, the production of lipids was altered to maintain membrane fluidity, and glycogen storage decreased in the liver of the sea bream (Ibarz et al., 2010a; Melis et al., 2017). Being a tropical and herbivorous species, the milkfish cannot survive in temperatures lower than $15^{\circ} \mathrm{C}$ and continue to use carbohydrates as their main energy resource (Chiu and Benitez, 1981; Benitez, 1983; Hu et al., 2015). On the other hand, when silver catfish (Rhamdia quelen), another tropical species, were transferred from $20^{\circ} \mathrm{C}$ to $15^{\circ} \mathrm{C}$, their hepatic glycogen degraded (Lermen et al., 2004). In the tropical white shrimp (Litopenaeus 

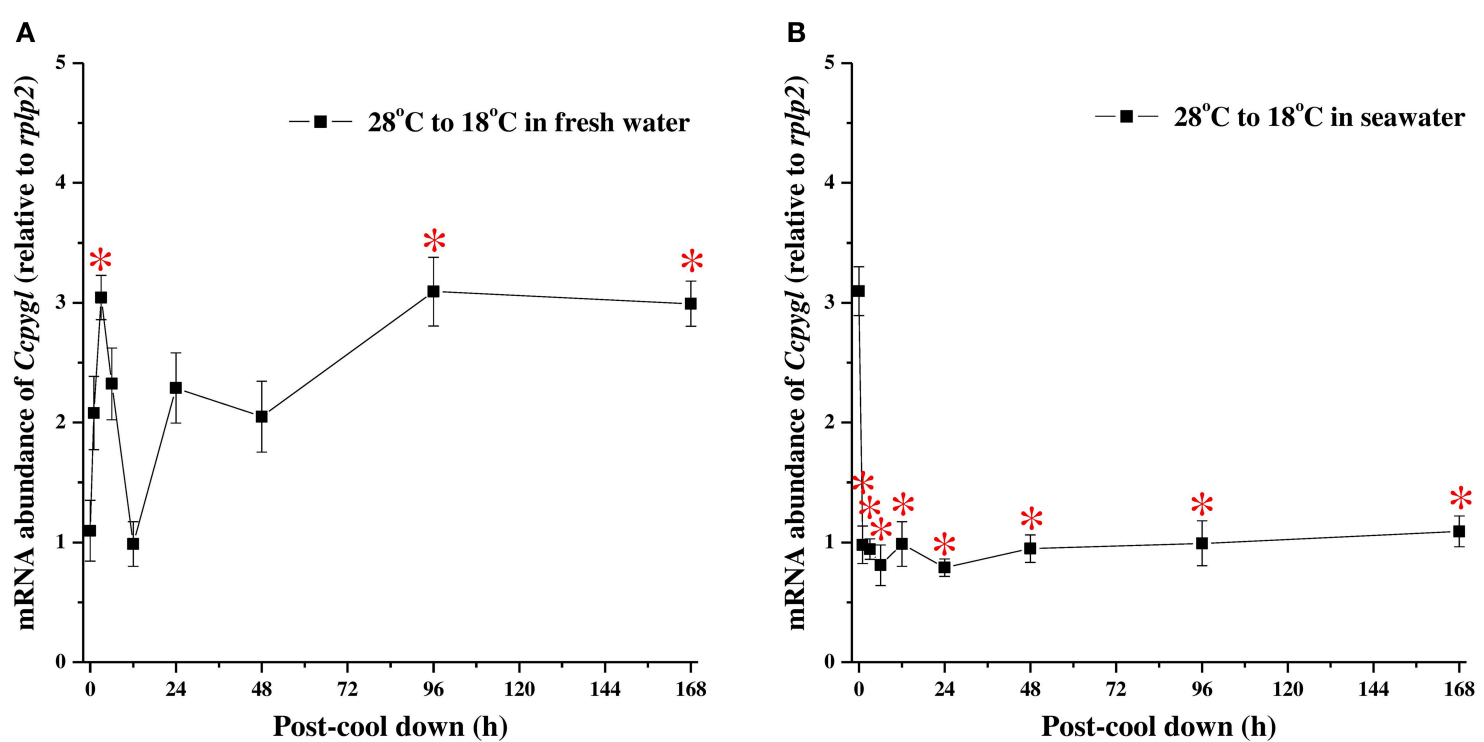

FIGURE 5 | The hypothermal stress experiments revealed time-course mRNA expression of Ccpygl in livers of (A) fresh water (FW) and (B) seawater (SW) milkfish. Values are means \pm SEM, $n=6$. The asterisks indicate significant differences $(P<0.05)$ compared to the $0 \mathrm{~h}$ fish using one-way ANOVA with Dunnett's test.

vannamei), the catabolism of glycogen was detected under cold stress (Zhou et al., 2011). In this study, hepatic glycogen degradation was also detected in FW-acclimated milkfish, but not in SW-acclimated milkfish, under hypothermal adaptation $\left(18^{\circ} \mathrm{C}\right)$. In aquatic organisms, hepatic glycogen storage or catabolism was affected by external temperature. When out of the optimal temperature range, reduction of feed intake and hepatic glycogen degradation were reported in aquatic organisms from tropical, subtropical, or temperate habitats. In addition, anti-oxidative responses under hypothermal stress were found in the livers of the zebrafish (Danio rerio), Nile tilapia (O. niloticus), and gilthead sea bream (Ibarz et al., 2010b; He et al., 2015; Wu et al., 2015). This antioxidant mechanism is energy consuming (Espinosa-Diez et al., 2015; Huang et al., 2015). The glycogen may be used in glycolysis to produce ATP or by the pentose phosphate pathway (Stanton, 2012). Then, the antioxidant system works depending on production of NADPH from the pentose phosphate pathway. Under hypothermal adaptation, FW milkfish encounter more oxidative stress in the liver than that by SW milkfish (Chang et al., 2016a,b, 2017). Therefore, the response of milkfish upon hypothermal and salinity stress may be correlated with the elevation of energy requirements.

\section{Regulation of Phosphorylation State of GP between FW and SW Milkfish under Cold Stress}

The activity of GP is regulated by the phosphorylation cycle, including the unphosphorylated $\mathrm{T}$ (tense)-state and phosphorylated R (relax)-state. The phosphorylation-state affected GP activity might be regulated by hormonal stimulation in the acute phase (Andersen and Westergaard, 2002; Milligan,
2003; Clow et al., 2008). The level of cortisol and glucagon-like peptide (GLP) in teleosts were suggested to play a role in elevating GP activity (Mommsen et al., 1999; Hallgen et al., 2003; Milligan, 2003). Barton and Peter (1982) found that the plasma cortisol levels of rainbow trout increased within $30 \mathrm{~min}$ and were maintained up to $4 \mathrm{~h}$ after rapid temperature decrease (from $10-11^{\circ} \mathrm{C}$ to $1^{\circ} \mathrm{C}$ ), whereas they were recovered to the normal level after $24 \mathrm{~h}$. Arjona et al. (2009) reported that plasma cortisol levels were increased 20-fold upon hypo-osmotic challenge in the Senegalese sole. In addition, $12^{\circ} \mathrm{C}$ exposure for $1 \mathrm{~h}$ induced an increase in the plasma cortisol levels in tilapia, whereas $19^{\circ} \mathrm{C}$ cold exposure did not cause this change (Chen et al., 2002). In addition, the GLP increased blood glucose levels via activation of gluconeogenesis in the livers of teleosts (Mojsov, 2000). The GLP levels of carp (Cyprinus carpio) blood were upregulated under acute changes in temperatures (Navarro et al., 2002). In the present study, after $12 \mathrm{~h}$ cold-exposure, increasing protein abundance of GP and phosphorylation levels along with an increase in GPase activity and decrease in glycogen content were found in the livers of FW milkfish, but not in SW milkfish. The total GP (R+T state) and GP (R state) allowed for identification of the elevated phosphorylation state of GP upon hypothermal stress in FW milkfish; however, no such change was noted in SW milkfish. The FW-acclimated juvenile milkfish had lower cold tolerance than the SW-acclimated fish (Kang et al., 2015). According to Milligan (2003), stress hormones might induce hepatic glycogen degradation to meet the glucose demands in FW milkfish under cold stress. Moreover, the GP activity in SW milkfish livers was not significantly different under cold stress, whereas downregulation of hepatic Ccpygl immediately after cold exposure in SW milkfish might be regulated via insulin or an insulin-like hormone (Klover and Mooney, 2004; Polakof et al., 2012). 


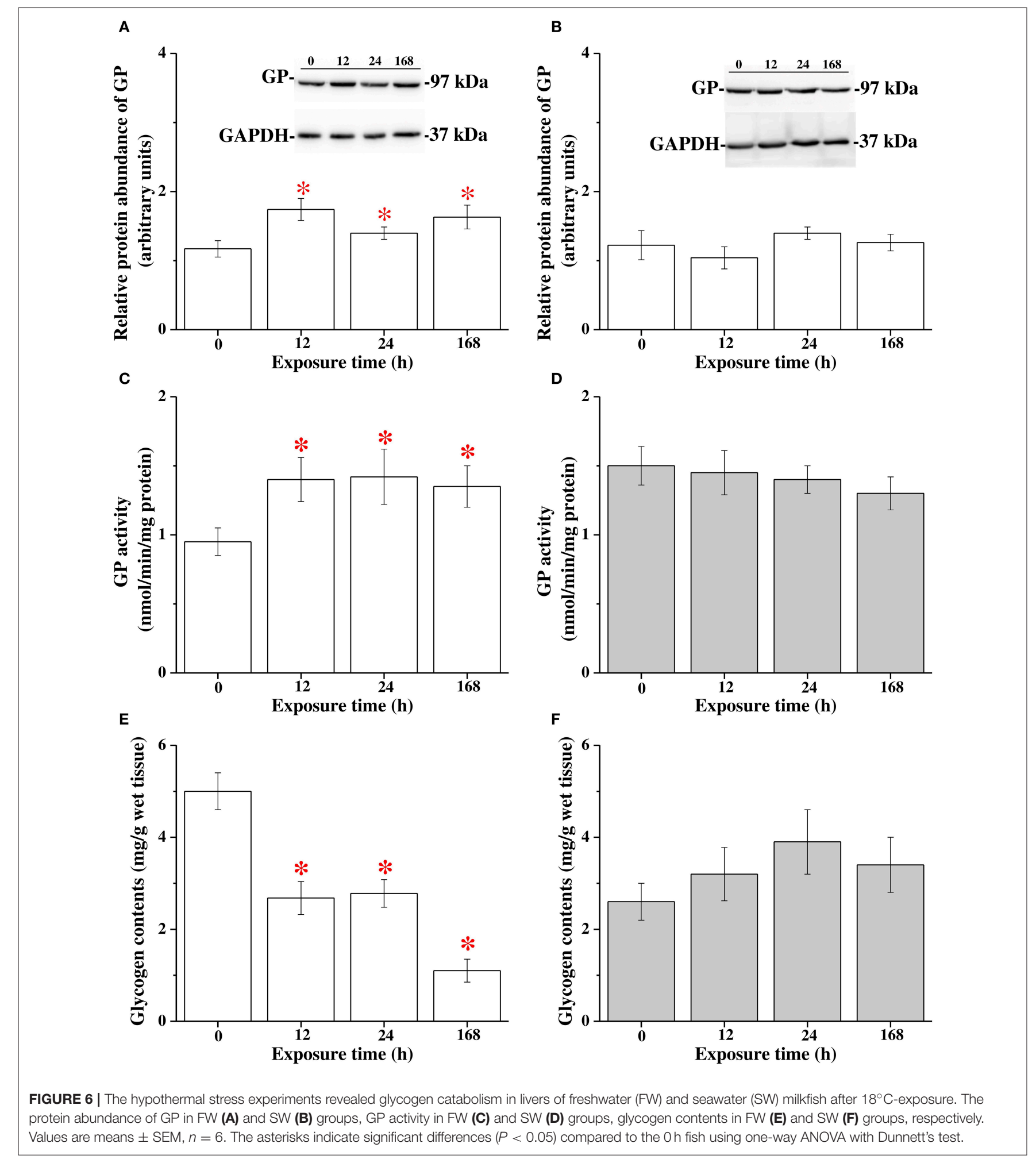

\section{CONCLUSION}

The results of the molecular, biochemical, and enzymatic analyses in this study illustrated the hypothermal effects on salinity-dependent glycogen utilization strategies in juvenile milkfish. In hypothermal acclimation, the feed intake of milkfish reduced in both FW and SW milkfish. However, only the FW milkfish upregulated hepatic glycogen catabolism to 

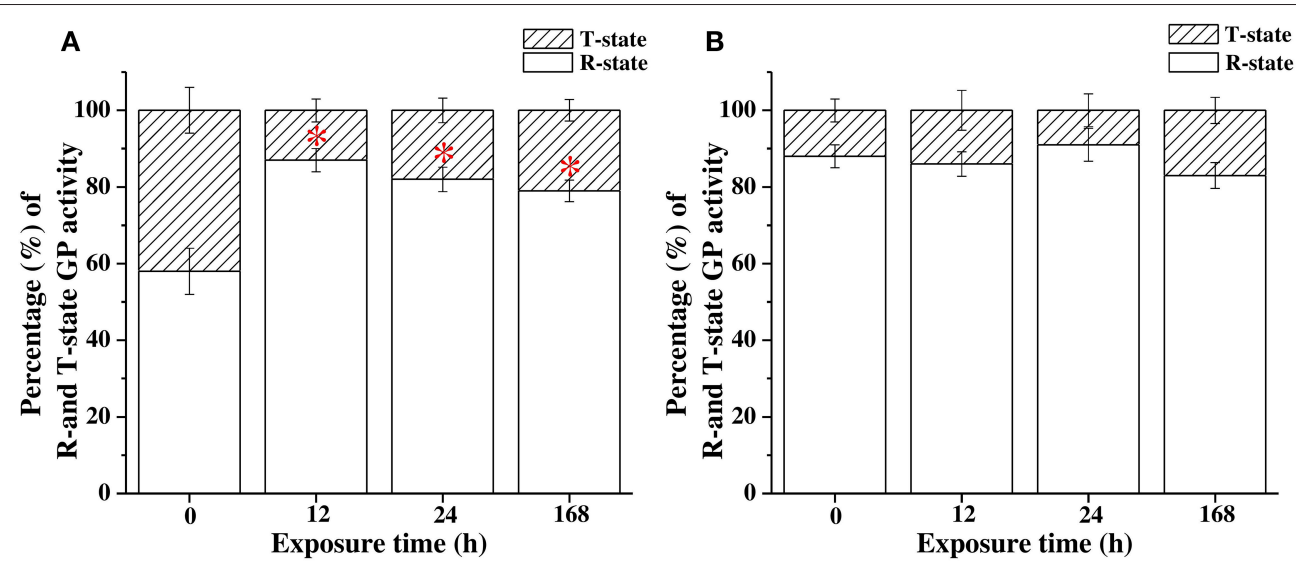

FIGURE 7 | The percentages of active form of GP activity in livers of (A) freshwater (FW) and (B) seawater (SW) milkfish in the hypothermal stress experiments after $18^{\circ} \mathrm{C}$-exposure. Values are means $\pm \mathrm{SEM}, n=6$. The percentage of the activity of GP active form: GP activity (AMP $\left.{ }^{-}\right) /$total GP activity $\left(\mathrm{AMP}^{+}\right) \times 100(\%)$. The asterisk indicates a significant difference compared to the $\mathrm{O}$ h fish by one-way ANOVA (Dunnett's comparison, $P<0.05$ ).

supply the energy required for acclimation to hypothermal stress. The phosphorylation state, protein abundance, and transcript levels of GP in milkfish livers were further found to be adjustable in the acute phase upon hypothermal challenge, corresponding to the salinity of the acclimated environment.

\section{AUTHOR CONTRIBUTIONS}

C-HC and T-HL conceived the study. C-HC, J-JH, and T-HL discussed and designed the experiments. C-HC, J-JH, C-YY, and $\mathrm{L}-\mathrm{YH}$ carried out the animal culture. C-HC, J-JH, and $\mathrm{C}-\mathrm{YY}$ performed the experiment. C-HC and T-HL contributed to writing the manuscript. Both authors read and approved the final manuscript. C-HT glycogen phosphorylase (GP)

\section{REFERENCES}

Agius, L. (2015). Role of glycogen phosphorylase in liver glycogen metabolism. Mol. Aspect Med. 46, 34-45. doi: 10.1016/j.mam.2015.09.002

Andersen, B., and Westergaard, N. (2002). The effect of glucose on the potency of two distinct glycogen phosphorylase inhibitors. Biochem. J. 367, 443-450. doi: 10.1042/bj20020153

Arjona, F. J., Vargas-Chacoff, L., Ruiz-Jarabo, I., Gonçalves, O., Páscoa, I., Martín del Río, M. P., and et al. (2009). Tertiary stress response in Senegalese sole (Solea senegalensis Kaup, 1858) to osmotic challenge: implications for osmoregulation, energy metabolism and growth. Aquaculture 287, 419-426. doi: 10.1016/j.aquaculture.2008.10.047

Arratia, G., and Bagarinao, T. (2010). "Early ossification and development of the cranium and paired girdles of Chanos chanos (Teleostei, Gonorynchiformes)," in Gonorynchiformes and Ostariophysan Relationships: A Comprehensive Review, eds T. Grande, F. J. Poyato-Ariza, and R. Diogo (New Hampshire: Science Publishers), 73-106.

Barton, B. A., and Peter, R. E. (1982). Plasma cortisol stress response in fingerling rainbow trout, Salmo gairdneri Richardson, to various transport conditions, anesthesia, and cold shock. J. Fish Biol. 20, 39-51. doi: 10.1111/j.1095-8649.1982.tb03893.x

Benitez, L. V. (1983). "Milkfish nutrition," in Advances in Milkfish Biology and Culture. Proceedings of the Second International Milk-Fish Aquaculture antibody and test of experimental condition of GP immunoblotting.

\section{FUNDING}

This study was supported by grants to T-HL from the Ministry of Science the Technology (MOST) of Taiwan (105-2313-B-005027-MY3).

\section{SUPPLEMENTARY MATERIAL}

The Supplementary Material for this article can be found online at: https://www.frontiersin.org/articles/10.3389/fphys. 2018.00081/full\#supplementary-material
Conference, eds J. V. Juario, R. P. Ferraris, and L. V. Benitez (Iloilo City: SEAFDEC/IDRC), 133-143.

Berg, J. M., Tymoczko, J. L., and Stryer, L. (2002). "Glycogen metabolism," in Biochemistry, 5th Edn., ed W. H. Freeman (New York, NY), 21.

Bolinger, M. T., and Rodnick, K. J. (2014). Differential effects of temperature and glucose on glycogenolytic enzymes in tissues of rainbow trout (Oncorhynchus mykiss). Comp. Biochem. Physiol. B. 171, 26-33. doi: 10.1016/j.cbpb.2014. 03.003

Chang, J. C., Wu, S. M., Tseng, Y. C., Lee, Y. C., Baba, O., and Hwang, P. P. (2007). Regulation of glycogen metabolism in gills and liver of the euryhaline tilapia (Oreochromis mossambicus) during acclimation to seawater. J. Exp. Biol. 210, 3494-3504. doi: 10.1242/jeb.007146

Chang, C. H., Lo, W. Y., and Lee, T. H. (2016a). The antioxidant peroxiredoxin 6 (Prdx6) exhibits different profiles in the livers of seawater- and fresh water-acclimated milkfish, Chanos chanos, upon hypothermal challenge. Front. Physiol. 7:580. doi: 10.3389/fphys.2016. 00580

Chang, C. H., Tang, C. H., Kang, C. K., Lo, W. Y., and Lee, T. H. (2016b). Comparison of integrated responses to nonlethal and lethal hypothermal stress in milkfish (Chanos chanos): a proteomics study. PLoS ONE 11:e0163538. doi: 10.1371/journal.pone.0163538

Chang, C. H., Yang, W. K., Lin, C. H., Kang, C. K., Tang, C. H., and Lee, T. H. (2016c). FXYD11 mediated modulation of $\mathrm{Na}+/ \mathrm{K}+$-ATPase activity 
in gills of the brackish medaka (Oryzias dancena) when transferred to hypoosmotic or hyperosmotic environments. Comp. Biochem. Physiol. A 194, 19-26. doi: 10.1371/journal.pone.0055470

Chang, C. H., Lin, J. Y., Lo, W. Y., and Lee, T. H. (2017). Hypothermal stress induced differential expression profiles of the immune response gene, warmtemperature-acclimation associated $65-\mathrm{kDa}$ protein (Wap65), in the liver of fresh water and seawater milkfish, Chanos chanos. Fish Shellish Immunol. 70, 174-184. doi: 10.1016/j.fsi.2017.09.012

Chen, W. H., Sun, L. T., Tsai, C. L., Song, Y. L., and Chang, C. F. (2002). Coldstress induced the modulation of catecholamines, cortisol, immunoglobulin M, and leukocyte phagocytosis in tilapia. Gen. Comp. Endocrinol. 126, 90-100. doi: $10.1006 /$ gcen.2001.7772

Chiu, Y. N., and Benitez, L. V. (1981). Studies on the carbohydrates in the digestive tract of the milkfish Chanos chanos. Mar. Biol. 61, 247-254. doi: $10.1007 / \mathrm{BF} 00386667$

Clow, K. A., Ewart, K. V., and Driedzic, W. R. (2008). Low temperature directly activates the initial glycerol antifreeze response in isolated rainbow smelt (Osmerus mordax) liver cells. Am. J. Physiol. Regul. Integr. Comp. Physiol. 295, 961-970. doi: 10.1152/ajpregu.90372.2008

Couto, A., Enes, P., Peres, H., and Oliva-Teles, A. (2008). Effect of water temperature and dietary starch on growth and metabolic utilization of diets in gilthead sea bream (Sparus aurata) juveniles. Comp. Biochem. Physiol. A 151, 45-50. doi: 10.1016/j.cbpa.2008.05.013

Enes, P., Panserat, S., Kaushik, S., and Oliva-Teles, A. (2008). Hepatic glucokinase and glucose-6-phosphatase response to dietary glucose and starch in gilthead sea bream (Sparus aurata) juveniles reared at two temperatures. Comp. Biochem. Physiol. A 149, 80-86. doi: 10.1016/j.cbpa.2007.10.012

Espinosa-Diez, C., Miguel, V., Mennerich, D., Kietzman, T., Sánchez-Pérez, P., Cadenas, S., and et al. (2015). Antioxidant responses and cellular adjustments to oxidative stress. Redox Biol. 6, 183-197. doi: 10.1016/j.redox.2015.07.008

Hallgen, N. K., Busby, E. R., and Mommsen, T. P. (2003). Cell volume affects glycogen phosphorylase activity in fish hepatocytes. J. Comp. Physiol. B 173, 591-599. doi: 10.1007/s00360-003-0369-1

Handeland, S. O., Imsland, A. K., and Stefansson, S. O. (2008). The effect of temperature and fish size on growth, feed intake, food conversion efficiency and stomach evacuation rate of Atlantic salmon post-smolts. Aquaculture 283, 36-42. doi: 10.1016/j.aquaculture.2008.06.042

He, J., Qian, J., Yang, H., Xu, P., Zhu, Z. X., and Yang, R. Q. (2015). Changes in the fatty acid composition and regulation of antioxidant enzymes and physiology of juvenile genetically improved farmed tilapia Oreochromis niloticus (L.), subjected to short-term low temperature stress. J. Therm. Biol. 53, 90-97. doi: $10.1016 /$ j.jtherbio.2015.08.010

Hu, Y. C., Kang, C. K., Tang, C. H., and Lee, T. H. (2015). Transcriptomic analysis of metabolic pathways in milkfish that response to salinity and temperature changes. PLoS ONE 10:e0134959. doi: 10.1371/journal.pone.0134959

Hu, Y. C., Chu, K. F., Yang, W. K., and Lee, T. H. (2017). Na+,K+-ATPase $\beta 1$ subunit associates with $\alpha 1$ subunit modulating a "higher-NKA-in-hyposmotic media response in gills of euryhaline milkfish, Chanos chanos. J. Comp. Physiol. B 187, 995-1007. doi: 10.1007/s00360-017-1066-9

Huang, C. Y., Lin, H. C., and Lin, C. H. (2015). Effects of hypoxia on ionic regulation, glycogen utilization and antioxidative ability in the gills and liver of the aquatic air-breathing fish Trichogaster microlepis. Comp. Biochem. Physiol. A 179, 25-34. doi: 10.1016/j.cbpa.2014.09.001

Ibarz, A., Blasco, J., Sala-Rabanal, M., Gallardo, A., Redondo, A., and FernándezBorràs, J. (2007). Metabolic rate and tissue reserves in gilthead sea bream (Sparus aurata) under thermal fluctuations and fasting and their capacity for recovery. Can. J. Fish Aquat. Sci. 64, 1034-1042. doi: 10.1139/ f07-079

Ibarz, A., Blasco, J., Gallardo, M. A., and Fernández-Borràs, J. (2010a). Energy reserves and metabolic status affect the acclimation of gilthead sea bream (Sparus aurata) to cold. Comp. Biochem. Physiol. A 155, 319-326. doi: 10.1016/j.cbpa.2009.11.012

Ibarz, A., Martín-Pérez, M., Blasco, J., Bellido, D., de Oliverira, E., and Fernández-Borràs, J. (2010b). Gilthead sea bream liver proteome altered at low temperatures by oxidative stress. Proteomics 10, 963-975. doi: 10.1002/pmic.200900528

Ibarz, A., Padros, F., Gallardo, M. A., Fernández-Borràs, J., Blasco, J., and Tort, L. (2010c). Low-temperature challenges to gilthead sea bream culture: review of cold-induced alterations and "Winter Synderom". Rev. Fish. Biol. Fish. 20, 539-556. doi: 10.1007/s11160-010-9159-5

Jana, S. N., Garg, S. K., and Patra, B. C. (2006). Effect of inland water salinity on growth performance and nutritional physiology in growing milkfish, Chanos chanos (Forsskal): field and laboratory studies. J. Appl. Ichthyol. 22, 25-34. doi: 10.1111/j.1439-0426.2006.00698.x

Johnson, L. N. (1992). Glycogen phosphorylase: control by phosphorylation and allosteric effectors. FASEB J. 6, 2274-2282.

Kang, C. K., Yang, W. K., Lin, S. T., Liu, C. C., Lin, H. M., Chen, H. H., et al. (2013). The acute and regulatory phases of time-course changes in gill mitochondria-rich cells of seawater-acclimated medaka (Oryzias dancena) when exposed to hypoosmotic environments. Comp. Biochem. Physiol. A 164, 181-191. doi: 10.1016/j.cbpa.2012.08.010

Kang, C. K., Chen, Y. C., Chang, C. H., Tsai, S. C., and Lee, T. H. (2015). Seawater-acclimation abates cold effects on $\mathrm{Na}+, \mathrm{K}+$-ATPase activity in gills of the juvenile milkfish, Chanos chanos. Aquaculture 446, 67-73. doi: 10.1016/j.aquaculture.2015.04.022

Klover, P. J., and Mooney, R. A. (2004). Hepatocytes: critical for glucose homeostasis. Int. J. Biochem. Cell Biol. 36, 753-758. doi: $10.1016 /$ j.biocel.2003.10.002

Laiz-Carrión, R., Sangiao-Alvarellos, S., Guzman, J. M., Martin del Rio, M. P., Soengas, J. L., and Mancera, J. M. (2005). Growth performance of gilthead sea bream Sparus aurata in different osmotic conditions: implication for osmoregulation and energy metabolism. Aquaculture 250, 849-861. doi: 10.1016/j.aquaculture.2005.05.021

Lermen, C. L., Lappe, R., Crestani, M., Vieira, V. P., Gioda, C. R., Schetinger, M. R., et al. (2004). Effect of different temperature regimes on metabolic and blood parameters of silver catfish Rhamdia quelen. Aquaculture 239, 497-507. doi: 10.1016/j.aquaculture.2004.06.021

Lin, Y. M., Chen, C. N., and Lee, T. H. (2003). The expression of gill Na, K-ATPase in milkfish, Chanos chanos, acclimated to seawater, brackish water and fresh water. Comp. Biochem. Physiol. A 135, 489-497. doi: 10.1016/S1095-6433(03)00136-3

Lin, Y. S., Tsai, S. C., Lin, H. C., Hsiao, C. D., and Wu, S. M. (2011). Changes of glycogen metabolism in the gills and hepatic tissue of tilapia (Oreochromis mossambicus) during short-term Cd exposure. Comp. Biochem. Physiol. C 154, 296-304. doi: 10.1016/j.cbpc.2011.06.014

Livak, K. J., and Schmittgen, T. D. (2001). Analysis of relative gene expression data using real-time quantitative PCR and the 2(-Delta Delta C(T)) method. Method 25, 402-408. doi: 10.1006/meth.2001.1262

Luz, R. K., Martinez-Alvarez, R. M., De Pedro, N., and Delgado, M. J. (2008). Growth, food intake regulation and metabolic adaptations in goldfish (Carassius auratus) exposed to different salinities. Aquaculture 276, 171-178. doi: 10.1016/j.aquaculture.2008.01.042

Martos-Sitcha, J. A., Mancera, J. M., Calduch-Giner, J. A., Yufera, M., MarinezRodriguez, G., and Perez-Sanchez, J. (2016). Unraveling the tissue-specific gene signatures of gilthead sea bream (Sparus aurata L.) after hyper- and hypoosmotic challenges. PLoS ONE 11:e0148113. doi: 10.1371/journal.pone.0148113

Melis, R., Sanna, R., Braca, A., Bonaglini, E., Cappuccinelli, R., Slawski, H., and et al. (2017). Molecular details on gilthead sea bream (Sparus aurata) sensitivity to low water temperature from $1 \mathrm{H}$ NMR metabolomics. Comp. Biochem. Physiol. A 204, 129-136. doi: 10.1016/j.cbpa.2016.11.010

Milligan, C. L. (2003). A regulatory role for cortisol in muscle glycogen metabolism in rainbow trout Oncorhynchus mykiss Walbaum. J. Exp. Biol. 206, 3167-3173. doi: $10.1242 /$ jeb.00538

Mojsov, S. (2000). Glucagon-like peptide-1 (GLP-1) and the control of glucose metabolism in mammals and teleost fish. Am. Zool. 40, 246-258. doi: $10.1093 / \mathrm{icb} / 40.2 .246$

Mommsen, T. P., Vijayan, M. M., and Moon, T. W. (1999). Cortisol in teleosts: dynamic mechanisms of action, and metabolic regulation. Rev. Fish Biol. Fish. 9,211-268. doi: 10.1023/A:1008924418720

Navarro, I., Rojas, P., Capilla, E., Albalat, A., Castillo, J., Montserrat, N., and et al. (2002). Insights into insulin and glucagon responses in fish. Fish Physiol. Biochem. 27, 205-216. doi: 10.1023/B:FISH.0000032726.78074.04

Near, T. J., Dornburg, A., and Friedman, M. (2014). Phylogenetic relationships and timing of diversification in gonorynchiform fishes inferred using nuclear gene DNA sequences (Teleostei: Ostariophysi). Mol. Phylogenet. Evol. 80, 297-307. doi: 10.1016/j.ympev.2014.07.013 
Payne, N. L., Smith, J. A., Meulen, D. E., Taylor, M. D., Watanabe, Y. Y., Takahashi, A., et al. (2016). Temperature dependence of fish performance in the wild: links with species biogeography and physiological thermal tolerance. Funct. Ecol. 30, 903-912. doi: 10.1111/1365-2435.12618

Polakof, S., Panserat, S., Sogngas, J. L., and Moon, T. W. (2012). Glucose metabolism in fish: a review. J. Comp. Physiol. B 182, 1015-1045. doi: 10.1007/s00360-012-0658-7

Pörtner, H. O., Peck, L., and Somero, G. (2007). Thermal limits and adaptation in marine Antarctic ectotherms: an integrative view. Phil. Trans. R. Soc. B 362, 2233-2258. doi: 10.1098/rstb.2006.1947

Pörtner, H. O. (2009). Oxygen- and capacity-limitation of thermal tolerance: a matrix for integrating climate-related stressor effects in marine ecosystems. J. Exp. Biol. 213, 881-893. doi: 10.1242/jeb.037523

Sangiao-Alvarellos, S., Arjona, F. J., Martin del Rio, M. P., Miguez, J. M., Mancera, J. M., and Soengas, J. L. (2005). Time course of osmoregulatory and metabolic changes during osmotic acclimation in Sparus auratus. J. Exp. Biol. 208, 4291-4304. doi: 10.1242/jeb.01900

Schram, E., Bierman, S., Teal, L. R., Haenen, O., Vis, H., and Rijnsdorp, A. D. (2013). Thermal preference of juvenile Dover Sole (Solea solea) in relation to thermal acclimation and optimal growth temperature. PLOS ONE 8:e61357. doi: 10.1371 /journal.pone.0061357

Singer, T. D., Raptis, S., Sathiyaa, R., Nichols, J. W., Playle, R. C., and Vijayan, M. M. (2007). Tissue-specific modulation of glucocorticoid receptor expression in response to salinity acclimation in rainbow trout. Comp. Biochem. Physiol. B 146, 271-278. doi: 10.1016/j.cbpb.2006.11.010

Soengas, J. L., Barciela, P., Fuentes, J., Otero, J., Andres, M. D., and Aldegunde, M. (1993). The effect of seawater transfer in liver carbohydrate metabolism of domesticated rainbow trout (Oncorhynchus mykiss). Comp. Biochem. Physiol. B 105, 337-343. doi: 10.1016/0305-0491(93)90238-Z

Stanton, R. C. (2012). Glucose-6-phosphat dehydrogenase, NAPDH, and cell survival. IUBMB Lifer. 64, 362-369. doi: 10.1002/iub.1017

Tang, C. H., Wu, W. Y., Tsai, S. C., Yoshinaga, T., and Lee, T. H. (2010). Elevated $\mathrm{Na}+/ \mathrm{K}+$-ATPase responses and its potential role in triggering ion reabsorption in kidneys for homeostasis of marine euryhaline milkfish (Chanos chanos) when acclimated to hypotonic fresh water. J. Comp. Physiol. B 180, 813-824. doi: 10.1007/s00360-010-0458-x

Tseng, Y. C., Huang, C. J., Chang, C. H., Teng, W. Y., Baba, O., Fann, M. J., and et al. (2007). Glycogen phosphorylase in glycogen-rich cells is involved in the energy supply for ion regulation in fish gill epithelia. Am. J. Physiol. Regul. Integr. Comp. Physiol. 293, 482-491. doi: 10.1152/ajpregu.00681. 2006

Varis, J., Haverinen, J., and Vornanen, M. (2016). Lowering temperature is the trigger for glycogen build-up and winter fasting in crucian carp (Carassius carassius). Zoolog. Sci. 33, 83-91. doi: 10.2108/zs150072

Vornanen, M., and Haverinen, J. (2011). Seasonality of glycogen phosphorylase activity in crucian carp (Carassius carassius L.). J. Comp. Physiol. B 181 917-926. doi: 10.1007/s00360-011-0580-4

Wu, S. M., Liu, J. H., Shu, L. H., and Chen, C. H. (2015). Anti-oxidative response of zebrafish (Danio rerio) gill, liver and brain tissues upon acute cold shock. Comp. Biochem. Physiol. A 187, 202-213. doi: 10.1016/j.cbpa.2015.05.016

Zhou, M., Wang, A. L., and Xian, J. A. (2011). Variation of free amino acid carbohydrate concentrations in white shrimp, Litopenaeus vannamei: effects of continuous cod stress. Aquaculture 317, 182-186. doi: 10.1016/j.aquaculture. 2011.04 .033

Conflict of Interest Statement: The authors declare that the research was conducted in the absence of any commercial or financial relationships that could be construed as a potential conflict of interest.

Copyright (c) 2018 Chang, Huang, Yeh, Tang, Hwang and Lee. This is an open-access article distributed under the terms of the Creative Commons Attribution License (CC $B Y)$. The use, distribution or reproduction in other forums is permitted, provided the original author(s) and the copyright owner are credited and that the original publication in this journal is cited, in accordance with accepted academic practice. No use, distribution or reproduction is permitted which does not comply with these terms. 